\title{
ISOLASI KAPANG PENDEGRADASI AMILUM PADA AMPAS SAGU (Metroxylon sagoo) SECARA IN VITRO
}

\author{
Rosmawati T, Dosen Program Studi Pendidikan Biologi, \\ Fakultas Ilmu Tarbiyah dan Keguruan, IAIN Ambon, \\ 085243144720, E-mail: rosmawati@ rocket.mail.co.id
}

\begin{abstract}
Abstrak: Tujuan penelitian ini adalah untuk mengetahui tentang bagaimana cara mengisolasi kapang pendegradasi amilum pada ampas sagu (Metroxylon sagoo) secara in vitro. Berdasarkan hasil penelitian menunjukan bahwa pada Isolat $I\left(C_{11}, C_{12}, C_{13}\right)$ dan Isolat III $\left(\mathrm{C}_{31}, \mathrm{C}_{32}, \mathrm{C}_{33}\right)$ kapang ampas sagu tidak mampu menghidrolisis amilum yang terdapat pada ampas sagu. Sedangkan pada Isolat II $\left(\mathrm{C}_{21}, \mathrm{C}_{22}, \mathrm{C}_{23}\right)$ menunjukan bahwa kapang ampas sagu mampu menghidrolisis amilum yang terdapat pada ampas sagu. Dengan demikian, kapang yang terdapat pada ampas sagu (Metroxylon sagoo) bisa diisolasi dan diidentifikasi untuk keperluan pengembangan sains dan terknologi bagi masyarakat.
\end{abstract}

\section{Kata Kunci: Kapang, Amilum, Ampas Sagu, Metroxylon Sagoo \\ ISOLATION of MOLD TO DEGRADATION STARCH DREGS on SAGO (Metroxylon sagoo) IN VITRO}

\begin{abstract}
Research purposes this is to know about how to isolate mildew to degradation amilum on dregs sago (Metroxylon sagoo) in vitro. Based on the research showed that isolates on I $\left(\mathrm{C}_{11}, \mathrm{C}_{12}, \mathrm{C}_{13}\right)$ and isolates III $\left(\mathrm{C}_{31}, \mathrm{C}_{32}, \mathrm{C}_{33}\right)$ mildew dregs sago incapable of hydrolyze amilum contained in dregs sago. While in isolates II $\left(\mathrm{C}_{21}, \mathrm{C}_{22}, \mathrm{C}_{23}\right)$ showed that mildew dregs sago capable of hydrolyze amilum contained in dregs sago. Thus, mildew contained in dregs sago (Metroxylon sagoo) could isolated and identified for development purposes science and terknologi for people.
\end{abstract}

Keywords: Mildew, Amilum, Dregs Of Sago, Metroxylon Sago 
Maluku sejak dahulu dikenal sebagai daerah yang penduduknya mengkonsumsi sagu sebagai makanan pokok masyarakatnya. Akan tetapi, seiring dengan perkembangan zaman pola hidup inipun berubah, masyarakat lebih senang memakan beras (nasi) sebagai makanan pokok. Hal ini menyebabkan sagu menjadi bahan makanan yang termarginalkan dan tidak diperhatikan perkembangannya padahal jumlahnya sangat banyak dan tersebar di seluruh daerah di Provinsi Maluku.

Sagu (Metroxylon sagoo) adalah salah satu tumbuhan penghasil karbohidrat dan merupakan bahan makanan pokok masyarakat Maluku, dimana dapat diposisikan sebagai komponen dalam membangun ketahanan pangan daerah. Propinsi Maluku memiliki pertanaman sagu yang cukup luas, yaitu sebesar 31.360 ha, dengan tingkat produksi tepung sagu $4.400 \mathrm{~kg} / \mathrm{ha}$, dapat menghasilkan limbah padat berupa ampas sagu sebanyak $26.400 \mathrm{~kg} / \mathrm{ha}$. Ampas sagu tersedia sebagai sumber energi bagi ternak, akan tetapi yang menjadi faktor pembatas adalah kandungan protein dan karbohidratnya (pati atau amilum) rendah dan serat kasar tinggi. Pati atau amilum adalah karbohidrat kompleks yang tidak larut dalam air, berwujud bubuk putih, tawar dan tidak berbau. Pati merupakan bahan utama yang dihasilkan oleh tumbuhan untuk menyimpan kelebihan glukosa (sebagai produk fotosintesis) dalam jangka panjang. Hewan dan manusia juga menjadikan pati sebagai sumber energi yang penting.

Pati atau amilum tersusun dari dua macam karbohidrat, amilosa dan amilopektin, dalam komposisi yang berbeda-beda. Amilosa memberikan sifat keras, sedangkan amilopektin menyebabkan sifat lengket. Amilosa memberikan warna ungu pekat pada tes iodin sedangkan amilopektin tidak bereaksi. Penjelasan untuk gejala ini belum pernah bisa tuntas dijelaskan. Bahan pangan yang mengandung karbohidrat cukup tinggi biasanya lebih banyak dirusak oleh kapang daripada jenis mikroba yang lainnya, karena karbohidrat merupakan substrat yang baik bagi pertumbuhan kapang dan khamir. Akan tetapi meskipun termasuk dalam fungi, kapang dan khamir memiliki perbedaan lingkungan hidup yang cukup berlawanan.

\section{METODE PENELITIAN}

Jenis penelitian ini adalah deskriptif kualitatif dengan pendekatan true eksperimen (eksperimen laboratorium) yang bertujuan untuk mengisolasi kapang pendegradasi amilum pada ampas sagu. Variabel dalam penelitian ini adalah variabel tunggal yaitu isolasi kapang pendegradasi amilum pada ampas sagu.

\section{Prosedur Penelitian}

1. Tahap Persiapan

a. Mempersiapkan semua alat dan bahan yang akan digunakan dalam penelitian. 
b. Melakukan sterilisasi pada alat-alat yang tahan pada suhu panas dengan menggunakan oven, dan mensterilisasi alat-alat yang tahan pada tekanan dengan menggunakan autoclave.

2. Tahap Pelaksanaan

a. Pembuatan PDA (Potato Dextrosa Agar)

1) Menimbang 10,5 gram PDA dan 1,5 gram kanji, kemudian dilarutkan dengan aquadest steril sampai volume $500 \mathrm{ml}$.

2) Memanaskan medium sambil mengaduk sampai medium homogen dan berwarna bening.

3) Mensterilisasi medium dengan menggunakan autoclave pada suhu $121^{\circ} \mathrm{C}$, tekanan 1 atm selama 15 menit.

b. Pembuatan PDB (Potato Dextrosa Brouth)

1) Menimbang 10,5 gram PDB dan melarutkan dengan aquadest steril sampai volume $500 \mathrm{ml}$.

2) Mengaduk medium sampai medium homogen.

3) Memasukkan PDB ke dalam labu erlenmeyer dengan volume $90 \mathrm{ml}$ dan ke dalam tabung reaksi dengan volume $9 \mathrm{ml}$.

c. Pembuatan PDA Plat dan PDA miring

1) Untuk PDA plat yaitu mencairkan media PDA yang telah steril ke dalam cawan petri steril kurang lebih $15 \mathrm{ml}$. Diamkan sampai memadat.

2) Untuk PDA miring yaitu memasukkan PDA ke dalam tabung reaksi kurang lebih $10 \mathrm{ml}$, kemudian disterilisasi dengan menggunakan autoclave selama 15 menit. Setelah steril, tabung reaksi yang telah berisi PDA ditempatkan dalam posisi miring sehingga permukaan medium dalam tabung reaksi akan miring.

3. Tahap Pengujian

a. Menimbang sampel ampas sagu sebanyak 10 gram, kemudian dimasukkan ke dalam medium PDB $(90 \mathrm{ml})$ dan dihomogenkan dengan menggunakan shaker selama 15 menit (Pengenceran $10^{-1}$ ).

b. Setelah sampel pada point "a" homogen, lalu diambil sebanyak $1 \mathrm{ml}$ secara aseptis dan dimasukkan ke dalam tabung reaksi yang berisi $9 \mathrm{ml}$ PDB. Homogenkan dengan menggunakan vortex selama 1 menit (Pengenceran $10^{-2}$ ).

c. Untuk pengenceran $10^{-3}$, maka diambil $1 \mathrm{ml}$ sampel pada point " $\mathrm{b}$ " dan dimasukkan ke dalam tabung reaksi yang berisi medium PDB $9 \mathrm{ml}$

d. Mengambil $1 \mathrm{ml}$ pada tabung di point "a, b, dan c", lalu disebarkan pada PDA Plat (masing-masing pengenceran diulang $3 \mathrm{kali}$ ). 
e. Menginkubasi cawan petri yang telah diisi sampel secara terbalik dalam incubator pada suhu $30^{\circ} \mathrm{C}$ selama $2 \times 24$ jam.

f. Koloni kapang pada cawan petri diuji kemampuannya dalam mendegradasi amilum dengan cara meneteskan iodium di sekitar koloni. Jika terbentuk zona bening, maka koloni kapang tersebut memiliki kemampuan untuk mendegradasi amilum.

g. Koloni yang teridentifikasi dalam mendegradasi amilum selanjutnya dimurnikan sebanyak 3 kali pada PDA miring sebagai isolat murni.

Adapun teknik pengumpula data dalam penelitian ini adalah:

1. Data primer, yaitu data yang diperoleh secara langsung oleh peneliti pada saat melakukan penelitian.

2. Data sekunder, yaitu data yang diperoleh dari berbagai literatur, berupa buku-buku paket, hasil-hasil penelitian sebelumnya, instansi terkait, dan sumber lain yang berkaitan dengan permasalahan yang diteliti.

\section{HASIL DAN PEMBAHASAN}

Berdasarkan hasil penelitian yang telah dilakukan tentang bagaimana cara mengisolasi kapang pendegradasi amilum pada ampas sagu (Metroxylon sagoo) secara in vitro dapat disajikan sebagai berikut:

Tabel 1. Pengujian Aktivitas Amilase

\begin{tabular}{|c|c|c|c|c|c|}
\hline Isolat I & Ket. & Isolat II & Ket. & Isolat III & Ket. \\
\hline $\mathrm{C}_{11}$ & - & $\mathrm{C}_{21}$ & + & $\mathrm{C}_{31}$ & - \\
\hline $\mathrm{C}_{12}$ & - & $\mathrm{C}_{22}$ & + & $\mathrm{C}_{32}$ & - \\
\hline $\mathrm{C}_{13}$ & - & $\mathrm{C}_{23}$ & + & $\mathrm{C}_{33}$ & - \\
\hline
\end{tabular}

Ket. : + : mampu menghidrolisis

- : tidak mampu menghidrolisis

Tabel pengujian aktivitas amilase di atas diperoleh setelah selama satu minggu melakukan penelitian. Hal ini dilakukan guna menumbuhkan kapang pada media pertumbuhan (media PDA) sehingga mudah untuk diisolasi. Koloni kapang pada media PDA diuji kemampuannya dalam mendegradasi amilum dengan cara meneteskan iodium di sekitar koloni. Jika terbentuk zona bening, maka koloni kapang tersebut memiliki kemampuan untuk mendegradasi amilum.

Dari data tersebut di atas memperlihatkan bahwa pada Isolat $\mathrm{I}\left(\mathrm{C}_{11}, \mathrm{C}_{12}, \mathrm{C}_{13}\right)$ dan Isolat III $\left(\mathrm{C}_{31}, \mathrm{C}_{32}, \mathrm{C}_{33}\right)$ kapang ampas sagu tidak mampu menghidrolisis amilum yang terdapat pada ampas sagu. Hal ini jelas terlihat pada saat pengamatan dilakukan, yakni setelah ditetesi iodium tidak terbentuk zona bening pada koloni kapang. Sedangkan pada Isolat II $\left(\mathrm{C}_{21}, \mathrm{C}_{22}, \mathrm{C}_{23}\right)$ menunjukan bahwa kapang ampas sagu mampu menghidrolisis amilum yang terdapat pada ampas sagu. Ini terlihat dengan adanya zona bening di sekitar 
koloni kapang setelah ditetesi iodium. Untuk lebih jelasnya perhatikan gambar hasil pengamatan di bawah ini:

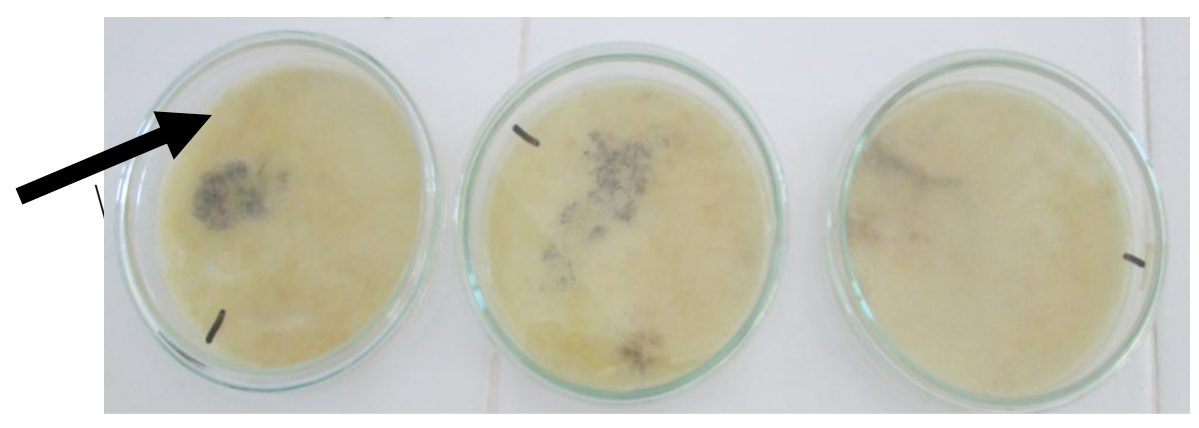

Gambar 1. Warna hitam di sekitar koloni kapang setelah ditetesi iodium.

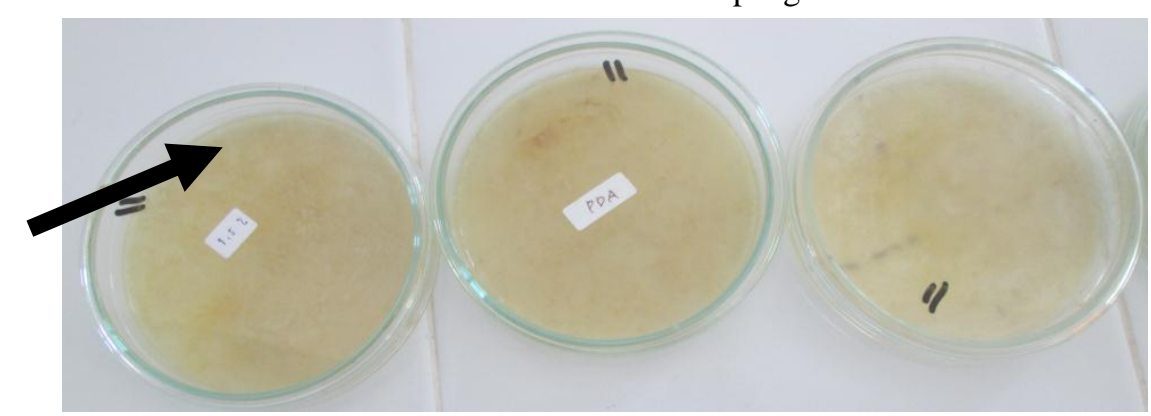

Gambar 2. Terbentuk warna bening di sekitar koloni kapang setelah ditetesi iodium.

Jika kita diperhatikan dua gambar di atas, maka pada gambar pertama menunjukan bahwa amilum pada ampas sagu tidak mampu dihidrolisis oleh kapang, karena terbentuk warna hitam di sekitar koloni kapang setelah ditetesi iodium. Warna hitam ini merupakan wujud dari oksidasi iodium terhadap amilum yang terdapat ampas sagu. Sedangkan pada gambar kedua terbentuk zona bening di sekitar koloni kapang setelah ditetesi iodium. Ini menunjukan bahwa kapang pada ampas sagu mampu menghidrolisis amilum pada ampas sagu. Morfologi kapang yang memilki kemampuan mendegradasi amilum yang diisolasi pada cawan petri $\mathrm{C}_{21}, \mathrm{C}_{22}$, dan $\mathrm{C}_{23}$ adalah sebagai berikut: 


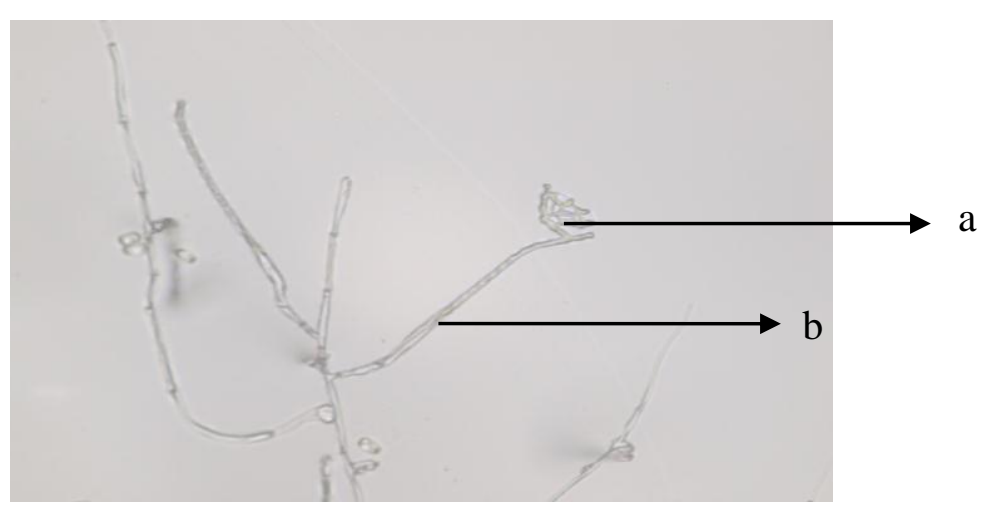

Gambar 3. Morfologi kapang pendegradasi amilum hasil isolat

$\mathrm{C}_{21}(\mathrm{a}=$ sporangium dan $\mathrm{b}=$ sporangiofor $)$

Gambar 3 di atas menunjukkan ciri morfologi kapang pendegradasi amilum yang memiliki sporangiofor dan sporangium. Bentuk hifa bersepta (bersekat) dan berwarna hialin. Morfologi kapang pendegradasi amilum pada cawan $\mathrm{C}_{22}$, dan $\mathrm{C}_{23}$ adalah sebagai berikut:

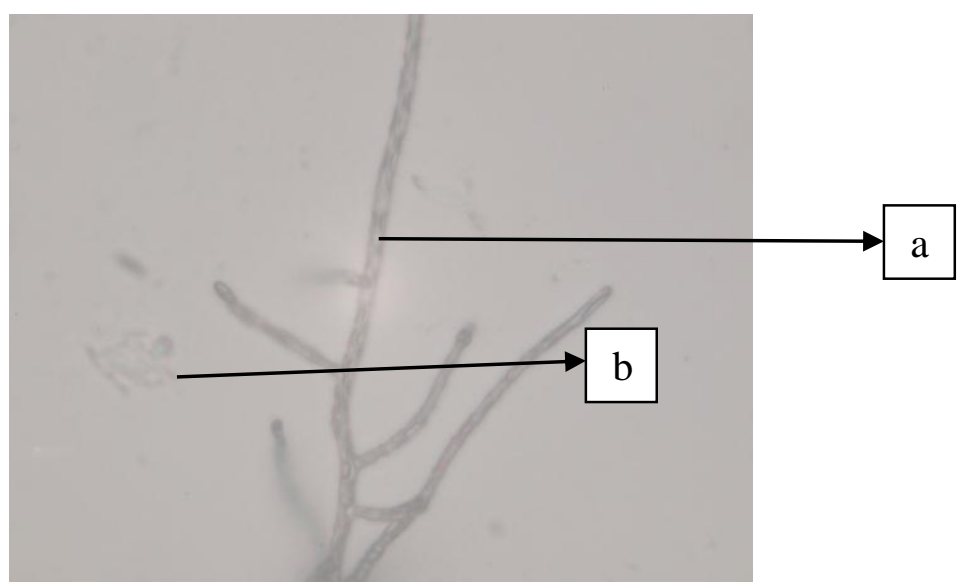

Gambar 4. Morfologi kapang pendegradasi amilum hasil isolat

$\mathrm{C}_{22}$ dan $\mathrm{C}_{23}(\mathrm{a}=$ sporangiofor dan $\mathrm{b}=$ sporangium $)$

Gambar 4 di atas menunjukkan adanya perbedaan morfologi kapang pendegradasi dengan hasil isolate pada cawan kode $\mathrm{C}_{21}$. Bentuk morfologi kapang gambar 4.4 tidak menunjukkan bentuk sporangium yang dominan membulat dan sporangiofornya berbentuk dikotom dengan warna hialin dan bersepta. Bentuk morfologi spora pada kapang hasil isolat pada cawan petri $\mathrm{C}_{21}, \mathrm{C}_{22}$, dan $\mathrm{C}_{23}$ adalah sebagai berikut 


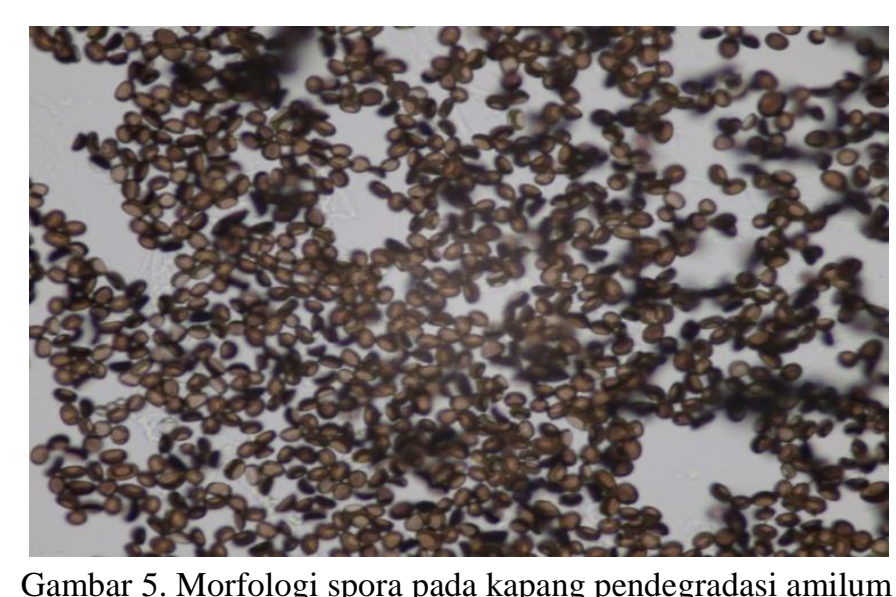

Gambar 5 di atas menunnjukkan morfologi spora pada kapang pendegradasi amilum dengan warna kecoklatan dan berbentuk bulat dan bagian tengah pipih. Pati atau amilum tersusun dari dua macam karbohidrat, amilosa dan amilopektin, dalam komposisi yang berbeda-beda. Amilosa memberikan sifat keras, sedangkan amilopektin menyebabkan sifat lengket. Amilosa memberikan warna ungu pekat pada tes iodin sedangkan amilopektin tidak bereaksi. Penjelasan untuk gejala ini belum pernah bisa tuntas dijelaskan. Bahan pangan yang mengandung karbohidrat cukup tinggi biasanya lebih banyak dirusak oleh kapang daripada jenis mikroba yang lainnya, karena karbohidrat merupakan substrat yang baik bagi pertumbuhan kapang dan khamir. Akan tetapi meskipun termasuk dalam fungi, kapang dan khamir memiliki perbedaan lingkungan hidup yang cukup berlawanan. Kapang membutuhkan air yang lebih sedikit daripada khamir.

\section{KESIMPULAN}

Cara mengisolasi kapang pendegradasi amilum pada ampas (Metroxylon sagoo) adalah dengan menumbuhkan kapang yang diambil dari ampas sagu dengan teknik pengenceran dan metode SPC dan dengan menggunakan medium diperkaya (PDA + Amilum). Kapang yang memiliki kemampuan mendegradasi ditandai dengan adanya reaksi bening setelah koloni kapang ditetesi iodium, dan jika tidak memiliki kemampuan dalam mendegradasi, maka di sekitar koloni kapang akan biru kehitaman setelah ditetsi iodium.

\section{SARAN}

1. Perlu adanya penelitian lebih lanjut mengenai identifikasi jenis-jenis kapang pendegradasi amilum pada ampas sagu (Metroxilon sagoo). 
2. Perlu dikembangkan lebih lanjut penelitian mengenai isolasi dan identifikasi jenisjenis kapang yang terdapat limbah tumbuhan lain, guna mengetahui kegunaannya untuk hajat hidup manusia

\section{DAFTAR PUSTAKA}

Alfons James Budidaya dkk. 2006 "Syarat Tumbuh Tanaman Sagu”. Malukulitbang. Deptan.

Bakosurtanal \& Ucen, 1983. Penerapan Pengindraan Jauh Untuk Penelitian Dan Pemetaan Penyebaran Areal Sagu Daerah, Irian Jaya.

BAlitBANG, 2005. Potensi Hutan Sagu, Kendala Pemanfaatan dan Prospek Pengembangannya. Balai Penelitian dan Pengembangan Kehutanan-Bogor.

BPPT. 1982, Hasil Survei Potensi Sagu Di Kep. Maluku. Bagian II. Kerja Sama BPPT dengan UNPATI.

Dwidjoseputro. D,. 2001, Dasar-Dasar Mikrobiologi. Penerbit Djambatan, Malang.

Een,S., Sumanti, D.S dan Hanidah, I. 2008., Mikrobiologi Pangan, Bahan Ajar Jurusan Teknologi Industri Pangan. FTIP. UNPAD. Bandung,

Fardiaz, S.1989. Mikrobiologi Pangan. Jurusan Teknologi Pangan dan Gizi. Fateta. IPB. Bogor.

Febiola Soakotta., 2008. Berkreasi dengan Limbah Sagu, Penerbit Selendang Ungu Press (SUP), Yogyakarta.

Hadioetomo, R. S. 1993. Mikrobiologi Dasar dalam Praktek : Teknik dan Prosedur Dasar Laboratorium. PT Gramedia Pustaka Utama, Jakarta.

Handayani, dkk. 2011. Penuntun Praktikum Mikrobiologi. Universitas Negeri Jakarta. Jakarta

Hehanusa Sylvia CH. H., 2006. Penampilan Ayam Broiler yang Diberi Ransum Mengandung Campuran Ampas Sagu-Ekstraksi Ayam Fermentasi. Prosiding Lokakarya Sagu dalam Revitalisasi Pertanian Maluku, Ambon 29-31 Mei 2006. Badan Penerbit Fakultas Pertanian Universitas Pattimura Ambon.

Hutapea Y., 1990. Sagu dan Manfaatnya. Buletin Balitka Nomor 12 September 1990 Deptan Bogor.

J.E. Louhenapessy, dkk. 2011. Sagu. Harapan dan Tantangan. Bumi Aksara, Jakarta.

Kaya Elizabeth., 2006. Pemanfaatan Ela Sagu sebagai Bahan Organik. Prosiding Lokakarya Sagu dalam Revitalisasi Pertanian Maluku, Ambon 29-31 Mei 2006. Badan Penerbit Fakultas Pertanian Universitas Pattimura Ambon.

Limbongan Jamia, Artikel 18 Agustus 2009 "Morfologi beberapa jenis sagu di Papua" http//pustaka. Deptan. Go. Id/p3261073. 
Louhanapessy Tejoyuwono Jujius E., 1992"Potensi Sagu Dalam Keanekaragaman Bahan Pangan Pokok Ditinjau Dari Persyaratan Lahan" Makalah untuk simposium Nasional. Diselenggarakan oleh UNPATI, PEMDA Tingkat I dan BPPT di Ambon.

Papilaya Chiljon Edy. 2009, "Sagu untuk Pendidikan Anak Negeri”. Cet 1 IP Press Bogor. Pelczar, M. J. dan Chan E.C.S. 2005, Dasar-Dasar Mikrobiologi (2). Jakarta: UI Press. 